\title{
ENCAPSULATION OF PHARMACEUTICALS INTO PECTIN AEROGELS FOR CONTROLLED DRUG RELEASE*
}

Gabrijela Tkalec, Željko Knez, Zoran Novak**

(ORIGINAL SCIENTIFIC PAPER) UDC 615.2:66.047.3

Faculty of Chemistry and Chemical Engineering, University of Maribor, Maribor, Slovenia

For this paper pectin aerogels were obtained by the sol-gel process and further supercritical drying with $\mathrm{CO}_{2}$. The materials were first characterised by nitrogen adsorption and scanning electron microscopy in order to investigate their structures. The highest yet reported surface area on pectin aerogels was achieved during this research $\left(590 \mathrm{~m}^{2} / \mathrm{g}\right)$. Then the drug loading was performed as the first step of the sol-gel process. Nicotinic acid was used as a model drug. Membranes were added to the pectin microsphere to control the release of nicotinic acid. The release of the model drug was investigated regarding triple and five membrane-aerogels. It was observed that the triple-membrane aerogel was unable to control the release. By adding the 5- membrane, the release decreased. $50 \%$ of the drug was released during the first hour followed by the slow first-order release up to $7 \mathrm{~h}$. The results clearly indicate that the addition of membranes on pectin aerogel has a significant impact on the drug release kinetics. The 5-membrane pectin aerogel showed potential to be a suitable carrier of the nicotinic acid after further research.
Keywords: supercritical drying, aerogel, drug delivery, pectin

\section{Introduction}

Aerogels are highly advanced materials now used in various applications. They are being used as thermal insulators, capacitors, drug carriers, active food materials in tissue engineering, and many others. They are prepared by the sol-gel process and later supercritical drying. Aerogels have been intensively studied as drug carriers, mostly due to their large surface areas and high porosities. Those properties are suitable either for controlling [1] the release of water-soluble drugs or for increasing the bio-availabilities of low-soluble drugs.

Initially inorganic, mostly silica aerogels were investigated for controlling the release of drugs. Later, organic aerogels were prepared and those aerogels also possess other advantages over silica aerogels, one of them being the biodegradability. In this manner, natural polysaccharide aerogels have been developed and investigated [2-4].

Pectin, as one of natural polysaccharides having gelling and stabilising abilities, is now extensively used in pharmaceutical and food applications. The two types of pectin have different properties and also gel under different mechanisms. Low ester pectin (LM) with a degree of esterification $\mathrm{DE}<50 \%$ gels in the presence of divalent ions [5] by the well-known egg-box model. Pectin is resistant to protease and amylase both of which are active within the upper gastrointestinal $(\mathrm{Gl})$ tract, and is digested by micro-flora in the lower GI tract. Therefore, it could work as a drug vehicle from the mouth to the intestines [6]. All these properties are promising for preparing pectin aerogels and using them to control the release of drugs.

\section{Experimental}

\section{Materials}

Low-methoxyl pectin (Herbstreith\&Fox). Calcium chloride $\left(\mathrm{CaCl}_{2}-\right.$ Kemika). Absolute ethanol (Sigma\&Aldrich).

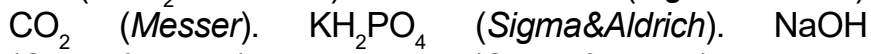
(Sigma\&Aldrich). Nicotinic acid (Sigma\&Aldrich).

Dissolution media were prepared according to standards [7]. Phosphate buffer solution (PBS) with $\mathrm{pH} 6.8$ was prepared by mixing $250.0 \mathrm{~mL}$ of $0.2 \mathrm{M}$ potassium di-hydrogen phosphate and $112 \mathrm{~mL}$ of $0.2 \mathrm{M}$ sodium hydroxide and diluted to $1000 \mathrm{~mL}$ with water. Simulated gastric fluid (SGF) was prepared by dissolving $2.0 \mathrm{~g}$ of sodium chloride and $3.2 \mathrm{~g}$ of pepsin powder in water. $80 \mathrm{~mL}$ of $1 \mathrm{M}$ hydrochloric acid was added to the solution and diluted to $1000 \mathrm{~mL}$ with water.

\section{Preparation of pectin aerogel}

The diffusion method was used to form wet gels from the pectin solution. Firstly, a $2 \%$ pectin solution was prepared and then transferred to an aqueous $0.2 \mathrm{M} \mathrm{CaCl}_{2}$

\footnotetext{
* Paper presented at the 11th Symposium "Novel Technologies and Economic Development", Leskovac, October, 23 - 24, 2015.

${ }^{* *}$ Author address: Zoran Novak, Faculty of Chemistry and Chemical Engineering, University of Maribor, Smetanova 17, SI-2000 Maribor, Slovenia

E-mail: zoran.novak@um.si

The manuscript received: June, 15, 2015.

Paper accepted: July, 14, 2015
} 
solution by using a syringe with a $0.8 \mathrm{~mm}$ nozzle. Fine spherical particles were formed. Those microspheres were then dehydrated within a series of water-ethanol baths of increasing the ethanol content $(10,30,50,70,90$, and $100 \%)$, and in this way, shrinkage was prevented during the solvent exchange. The alcogels were then super-critically dried at $40^{\circ} \mathrm{C}$ and 100 bar. Such prepared aerogels were used for the characterisation.

Drug-loaded aerogels were prepared by the same procedure. An additional step was the addition of the model drug during the first step of the sol-gel process. Nicotinic acid was added to the pectin aqueous solution before the cross-linking. Later during the process of adding membranes, inner surfaces between the core and membrane and between two membranes were filled with the model drug. The further process for obtaining aerogels was the same as described above, including immersion of hydrogels within a series of excessive ethanol baths and later supercritical drying. All the solutions for cross-linking and solvent exchange were saturated with the model drug to prevent diffusion from the carrier.

\section{Characterisation}

The prepared aerogels were characterised by swelling experiments, $\mathrm{N}_{2}$ adsorption, and scanning electron microscopy.

The surface morphologies of the pectin aerogels were determined using a Sirion 400 NC scanning electron microscope (SEM). The samples were sputter-coated with gold particles and then scanned at an accelerating voltage of $5 \mathrm{kV}$.

Nitrogen adsorption was performed for determining the surface areas, pore sizes and pore volumes of the prepared aerogels, using a Micrometrics ASAP 2020MP porosimeter.

For swelling studies, a sample of multi-membrane spherical aerogel was weighted into a beaker containing $40 \mathrm{ml}$ of either simulated gastric fluid (SGF) at $\mathrm{pH} 1.2$ or phosphate buffer at $\mathrm{pH} 6.8$, thus mimicking the condition of the gastrointestinal tract. The sample was withdrawn after a pre-selected period of time, blotted dry with tissue paper and weighted. At least three measurements were carried out for each sample in each solution. The swelling ratio was calculated according to equation (1):

Swelling ratio $=\frac{M_{t}}{M_{0}}$......
Where $M_{t}$ is the mass of the swollen gel monolith after time $t$ and $M_{0}$ is the initial mass of the dry aerogel monolith.

\section{Determination of the drug content}

The drug-loaded aerogel sample was poured into $100 \mathrm{ml}$ of phosphate buffer solution. After $10 \mathrm{~min}$ of sonicating and $6 \mathrm{~h}$ of stirring at $250 \mathrm{rpm}$ and $37 \pm 1{ }^{\circ} \mathrm{C}$, the solution was filtered through a TEFLON $0.45 \mu$ filter and the amount of a drug was determined spectrophotochemically (Varian, Cary 50 Probe UV spectrophotometer). Drug loading ( $D L)$ of nicotinic acids was calculated by equation (2), assuming complete drug extraction:

$D L=\frac{m_{d}}{m_{s}} \cdot 100 \%$

Here md is the mass of the drug (mg), obtained by UV analysis and $\mathrm{ms}$ is the initial mass of the weighted aerogel sample. Each test was done in triplicate.

\section{Drug dissolution test}

In-vitro dissolution tests for both model drugs were performed on FARMATESTER-3 USP 2 apparatus (paddle). The aerogel sample was poured into $900 \mathrm{ml}$ of the phosphate buffer $(\mathrm{pH} 6.8)$ solution that was thermostated to $37 \pm 0.5^{\circ} \mathrm{C}$ and the rotation speed was $50 \mathrm{rpm}$. The sample was left under stirring for $24 \mathrm{~h}$. Aliquots $(2 \mathrm{~mL})$ of dissolution media were withdrawn at selected time intervals and each time $2 \mathrm{ml}$ of the fresh buffer solution was added to the media to maintain the constant volume. The withdrawn samples were passed through a $0.45 \mu \mathrm{m}$ filter and then analysed using UV spectrophotometry (Model Varian, Cry 50 Probe spectrophotometer) at the wavelength of $262 \mathrm{~nm}$ for nicotinic acid. Cumulated amounts released (in percentages of the initial amounts) were plotted vs. time.

\section{Results and Discussion}

\section{Characterisation}

The core ( $2 \%$ pectin solution) and membrane ( $1 \%$ pectin solution) from the spherical sample were compared in Figure 1. The core looked more uniformly cross-linked in comparison with the surface of the membrane. This could be due to the longer time of cross-linking and a higher concentration of pectin in the core.

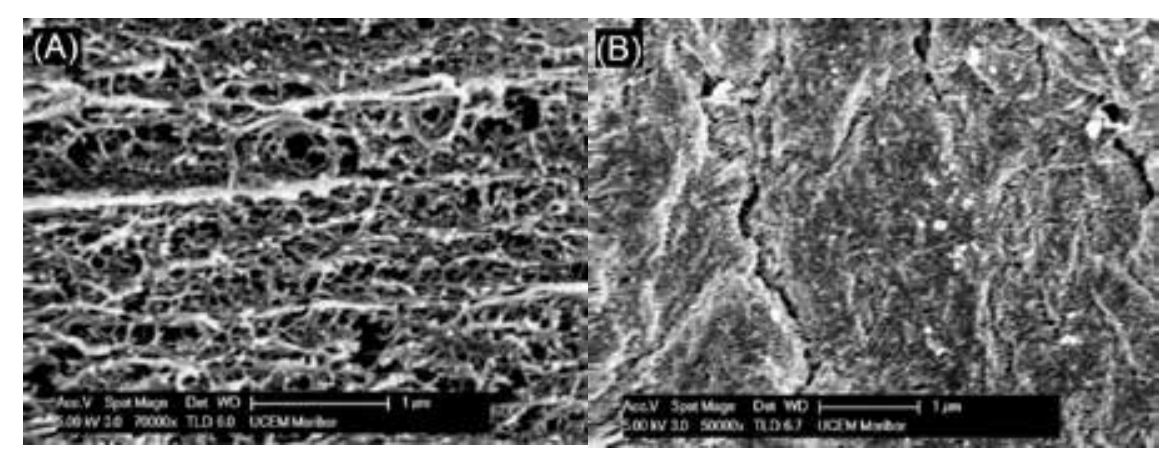

Figure 1. SEM images of pectin (A) membrane and (B) spherical core. 
Nitrogen adsorption measurements provided outstanding results on the surface area of spherical aerogels (Table 1). Namely, the surface area of the core was $544 \mathrm{~m}^{2} / \mathrm{g}$ and that of the membrane even higher at $593 \mathrm{~m}^{2} / \mathrm{g}$. This is the highest yet reported surface area on pectin aerogels $[8,9]$. From the sizes of the pores, as well as from the types of isotherms (class IV), it could be concluded that all the pectin aerogel samples were of mesoporous materials.

Table 1. Effect of the pectin type and concentration on the characteristics of the monolithic and spherical aerogel samples.

\begin{tabular}{cccc}
\hline $\begin{array}{c}\text { Pectin } \\
(\%)\end{array}$ & $\begin{array}{c}\text { Sbet of aerogel } \\
\left(\mathrm{m}^{2} / \mathrm{g}\right)\end{array}$ & $\begin{array}{c}\text { Pore volume } \\
\text { aerogel }\left(\mathrm{cm}^{3} / \mathrm{g}\right)\end{array}$ & $\begin{array}{c}\text { Average pore } \\
\text { diameter }(\mathrm{nm})\end{array}$ \\
\hline Membrane 1.0 & $593 \pm 10$ & $1.64 \pm 0.03$ & $12.0 \pm 3.3$ \\
Core 2.0 & $544 \pm 8$ & $3.27 \pm 0.03$ & $26.3 \pm 2.3$ \\
\hline
\end{tabular}

Swelling experiments were carried out at $\mathrm{pH}$ conditions mimicking those of the stomach $(\mathrm{pH} 1.2)$ and of the intestine ( $\mathrm{pH} 6.8)$. The swelling ratio in the SGF remained near constant during $8 \mathrm{~h}$. Oppositely, the swelling of the pectin was strongly influenced by the higher $\mathrm{pH}$ of the phosphate buffer leading to a degradation of the sample (Figure 2).

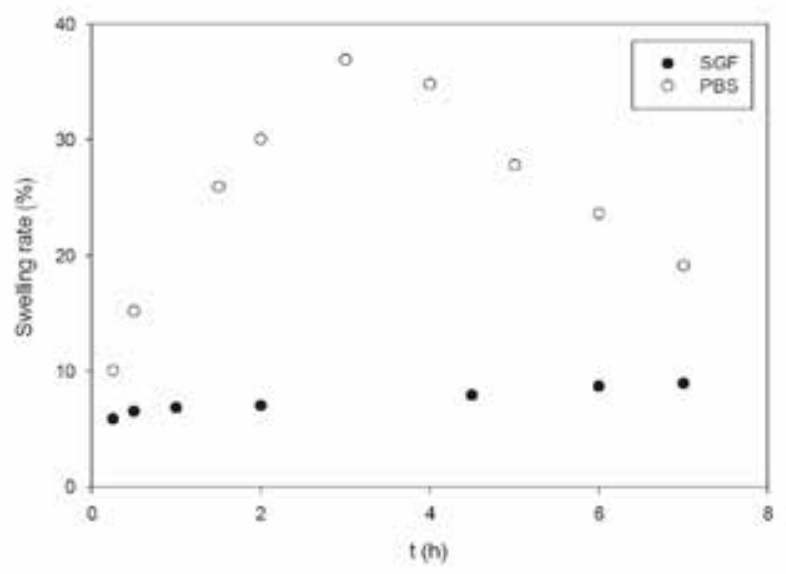

Figure 2. Swelling of spherical samples in simulated gastric fluid (SGF) and in phosphate buffer solution (PBS).

\section{Dissolution of nicotinic acid from multi-membrane} pectin aerogels

Pectin aerogels provided $37 \%$ loading of the model drug. Nicotinic acid is good-soluble and highly permeable at $\mathrm{pH} 6.8$. Thus the carrier characteristics are important to prolonging the releases of the model drugs. Figure 3 displays dissolution profiles of nicotinic acid (NA) from multi-membranes.

It was shown that the 5-membrane aerogels demonstrated better dissolution and more controlled release than the triple-membrane aerogels.

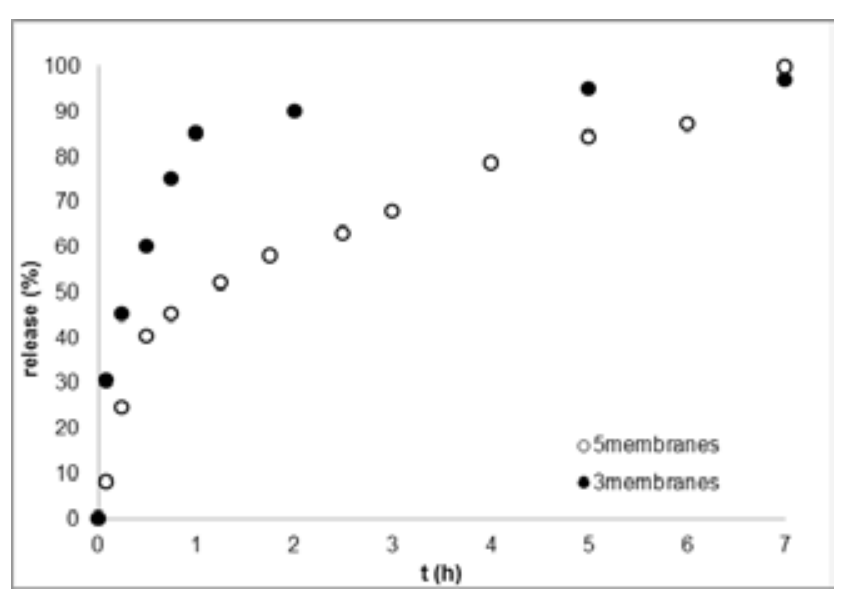

Figure 3. Nicotinic acid releases from triple-membrane and 5-membrane aerogels.

The initial burst release of nicotinic acid happened during the first hour, followed by the slow and sustained drug release noted from the triple-membrane carrier.

\section{Conclusions}

In this research, biodegradable low-methoxyl aerogels were prepared by the diffusion method. Nitrogen adsorption gave highly promising results on specific surface areas. The highest specific surface area $\left(593 \mathrm{~m}^{2} / \mathrm{g}\right)$ of the spherical pectin aerogels was obtained in comparison with the data reported by other research groups $[8,9]$. As surface area/volume is one of the key variables in controlling the drug release, different aerogel characteristics can be obtained by changing the types, degrees of esterification or amidation and the concentration of the pectin, thus influencing the drug release. 5-membrane aerogels provided a better dissolution rate with $100 \%$ release after $7 \mathrm{~h}$. With the addition of membranes, a slower release can be expected due to the longer diffusion pathway.

\section{Acknowledgements}

The authors wish to acknowledge the Slovenian Research Agency for its financial support.

\section{Abbreviations}

DE - degree of esterification

DL - drug loading

GI - gastrointestinal tract

LM - low methoxyl (low ester) pectin

NA - nicotinic acid

Sbet - specific surface area, determined by the Brunauer-

Emmett-Teller method

SEM - scanning electron microscopy

SGF - simulated gastric fluid 


\section{References}

[1] T.D. Reynolds, S.A. Mitchell, K.M. Balwinski, Investigation of the Effect of Tablet Surface Area/Volume on Drug Release from Hydroxypropylmethylcellulose ControlledRelease Matrix Tablets, Drug Dev. Ind. Pharm. 28 (2002) 457-466.

[2] T. Mehling, I. Smirnova, U. Guenther, R.H.H. Neubert, Polysaccharide-based aerogels as drug carriers, Journal of Non-Crystalline Solids. 355 (2009) 2472-2479.

[3] M. Alnaief, M.A. Alzaitoun, C.A. García-González, I. Smirnova, Preparation of biodegradable nanoporous microspherical aerogel based on alginate, Carbohydrate Polymers 84 (2011) 1011-1018.

[4] C.A. García-González, E. Carenza, M. Zeng, I. Smirnova, A. Roig, Design of biocompatible magnetic pectin aerogel monoliths and microspheres, RSC Advances 2 (2012) 9816-9823.

[5] P. Sriamornsak, Chemistry of pectin and its pharmaceutical uses: A review, Silpakorn University International Journal
3 (2003) 206-228.

[6] L. Liu, M.L. Fishman, J. Kost, K.B. Hicks, Pectin-based systems for colon-specific drug delivery via oral route, Biomaterials. 24 (2003) 3333-3343. doi:10.1016/S01429612(03)00213-8.

[7] Council of Europe, Recommendations on methods for dosage forms testing, in: Eur. Pharmacopoeia 80, 2010: pp. 727-729.

[8] C.A. García-González, M. Alnaief, I. Smirnova Polysaccharide-based aerogels-Promising biodegradable carriers for drug delivery systems, Carbohydrate Polymers 86 (2011) 1425-1438.

[9] R.J. White, V.L. Budarin, J.H. Clark, Pectin-derived porous materials, Chemistry - A European Journal 16 (2010) 1326-1335. doi:10.1002/chem.200901879.

\section{Izvod \\ INKAPSULACIJA FARMACEUTSKI AKTIVNIH SUPSTANCI U PEKTINSKIM AEROGELOVIMA U CILJU POSTIZANJA KONTROLISANOG OSLOBAĐANJA}

Gabrijela Tkalec, Željko Knez, Zoran Novak

Fakultet za hemiju i hemijsko inženjerstvo, Univerzitet u Mariboru, Maribor, Slovenija

Za ovu svrhu pektinski aerogelovi su dobijeni sol-gel procesom i u drugom koraku superkritičnim sušenjem pomoću superkritičnog ugljen-dioksida. Materijali su prvo karakterisani adsorpcijom azota i SEM mikroskopijom u cilju određivanja njihove strukture. Tokom ovog istraživanja je postignuta do sada najviša prijavljena specifična površina pektinskih aerogelova $\left(590 \mathrm{~m}^{2} / \mathrm{g}\right)$. Za potrebe farmaceutskih aplikacija, aerogelovi su napunjeni aktivnom supstancom u prvom koraku sol-gel procesa. Nikotinska kiselina je korišćena kao model supstanca. Membrane su dodate na pektinske mikrosfere u cilju kontrolisanja otpuštanja nikotinske kiseline. Otpuštanje nikotinske kiseline je istraženo iz tromembranskih i petomembranskih aerogelova. Primećeno je, da tromembranski aerogelovi nisu bili u stanju da kontrolišu otpuštanje supstance. Dodavanjem pet membrani otpuštanje je usporeno. $50 \%$ supstance je otpuštno u prvom satu nakon čega je praćeno sporim otpuštanjem do sedmog sata. Rezultati jasno ukazuju, da je dodavanjem membrana na pektinske aerogelove izvršen značajan uticaj na kinetiku otpuštanja supstance. Petomembranski pektinski pokazao je potencijal da, nakon daljnih istraživanja, bude ogovarajući nosač za isporuku nikotinske kiseline u telu.
(ORIGINALNI NAUČNI RAD) UDK 615.2:66.047.3

Ključne reči: superkritično sušenje, aerogel, raspodela lekova, pektin 